\title{
The Impact of Obesity on Fertility
}

\author{
Manish Motwani* \\ Bariatric surgeon, India \\ Received: May 16, 2018; Published: July 20, 2018 \\ *Corresponding author: Manish Motwani, Bariatric surgeon, India, Email: dr.manish.motwani@gmail.com
}

Keywords: Obesity; Reproductive health; Bariatric surgery; Infertility

\section{Introduction}

When we speak about obesity, many other comorbid conditions are associated with it. One of them being infertility. The pains of not being able to conceive a child is something that only couples can understand. But however, if the cause is morbid obesity then this complication can be resolved. The prevalence of obesity and overweight are increasing worldwide putting women at a major risk of reproductive health. With morbid obesity on the rise, this health concern has become a worldwide epidemic. Obesity has detrimental influences on all systems, including reproductive health. It is a complex disorder and its related comorbidities impair fertility, maternal health during pregnancy, maternal outcomes of pregnancy, fetal outcomes and long-term health of the offspring, menstrual dysfunction, PCOS, Type 2 diabetes, joint pain, gastroesophageal reflux and sleep disorders.

The reason for infertility arises because of the excess weight due to which hormonal functioning is disrupted causing irregular ovulation which leads to PCOS-again putting a threat to the chances of becoming pregnant. It forms a vicious cycle leading from one event to the other. The link between obesity and infertility have been known since years and the research is on. However, the exact mechanism cannot be described since it is multifactorial and not based on one cause. In these cases, weight loss has proven very beneficial to women to be able to conceive. Conservative management inclusive of lifestyle changes, followup with the dietitian and psychotherapy are the prerequisites to managing obesity.

However, people suffering from morbid obesity are unlikely to achieve management goals based on lifestyle changes as that is something more complex and that is when the weight loss surgery comes into the picture. The surgery helps reduce weight overtime and remains the most clinically effective and cost-effective intervention for people with morbid obesity. With PCOS linked to weight gain, Research says that Bariatric Surgery can help solve infertility problems by improved menstrual irregularity and resolve anovulation. The National Institute of Health indications for bariatric surgery includes more than $100 \mathrm{lbs}$ or $45 \mathrm{~kg}$ of the ideal body weight, Body Mass Index of $40 \mathrm{~kg} / \mathrm{m}^{2}$ or BMI of $35-39.9 \mathrm{~kg} / \mathrm{m}^{2}$ with one or more associated comorbidities of diabetes, cardiovascular diseases or sleep apnoea.

Bariatric surgery has made much difference in the lives of women who were struggling with infertility says Dr. Manish Motwani-a renowned bariatric surgeon based in Mumbai. He further adds, "I have had so many patients come to me, saying that they have problems with conceiving. The major cause that stands here is obesity. It is such as issue that has created problems in other circles of life too. The patients have claimed to me that they can't have a complete family and they cannot have a child even after resorting to IVF. I would say that Bariatric surgery can help solve and has actually solved many of the problems in these patients and they themselves have seen visible differences in their weight, obviously also keeping a watch on the lifestyle and diet intake.

The procedure is safe and should be adopted by patients who wish to start a family. Thus, women trying to conceive should achieve significant weight loss to have a successful surgery and this is where bariatric surgery proves to be a boon indeed. Lastly, although weight loss surgery is the gold treatment in women with a High BMI, emphasis should also be laid on a healthy living to prevent further associated comorbidities. 


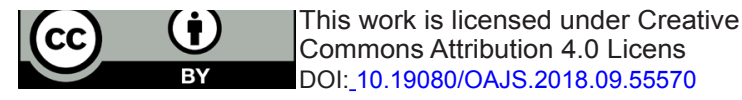

Your next Submission with Juniper Publishers
will reach you the below assets
- Quality Editorial service
- Swift Peer Review
- Reprints availability
- E-prints Service
- Manuscript Podcast for convenient understanding
- Global attainment for your research
- Manuscript accessibility in different formats
( Pdf, E-pub, Full Text, Audio)
- Unceasing customer service
Track the below URL for one-step submission
https://juniperpublishers.com/online-submission.php

